\title{
Minorities, Territoriality and Politics for Autonomy: An Analysis of Competing Ethnic Politics in Eastern Sri Lanka
}

\author{
Mohammad Agus Yusoff \\ Center for Policy and Global Governance, \\ Faculty of Social Sciences and Humanities, \\ Universiti Kebangsaan Malaysia, \\ UKM Bangi 43600, Selangor, Malaysia \\ Athambawa Sarjoon \\ Department of Political Science, \\ Faculty of Arts, University of Peradeniya, \\ Peradeniya-20400, Sri Lanka
}

Zawiyah Mohd Zain

College of Law, Government and International Studies, Universiti Utara Malaysia, UUM Sintok 06010,

Kedah, Malaysia

Doi: 10.2478/ajis-2019-0018

\begin{abstract}
Regional politics play a decisive role in national politics when region poses ethnic groups in competing manner. Sri Lanka's Eastern province has been a contested region in terms of ethnic and territorial integration as well as the integration of majority and minorities from the independence of the country, during civil war, and in the post-civil war era. This study explores the ethnic groups' competition for political control and autonomy, as well as its impact in Eastern Sri Lanka. This study has employed both qualitative and quantitative data, collected mainly through secondary sources such as literary books, book chapters, journal articles, newspaper cuttings, and government documents, which are analyzed and presented through interpretive and descriptive manners. The study has found that the Eastern province has been a contested choice for the ethnic majority to extend their ethnic domination, and to implement ethno-centric development-cum settlement policies and programs, all of which are ultimately induced to change the ethnic composition of the region and pushed ethnic minorities to mobilize and demand for more decentralized power and autonomy in the region. The thirty-year prolonged civil war made the region not only a war-torn, but also let to undermining regional democratic principles, including minorities' rights for autonomy. The study also reveals that the new emerging post-war political context at the provincial and national levels continues to undermine the minorities' hopes for autonomy in the region. Nevertheless, the region has emerged as 'role-model' for ethnic cohesive politics.
\end{abstract}

Keywords: Regional politics, regional autonomy, ethnic minorities, Sri Lanka's Eastern province

\section{Introduction}

Sri Lanka, like many plural states, has also been severely suffering due to claims and mobilization of ethnic minorities towards more autonomy and self-rule in their traditionally inhabited areas. Sri 
Lanka's Eastern province has been a contested region for ethnic and power politics, which brought the region politically important and influential in the post-independent era of regional development, administration and governance. The settlement pattern of ethnic groups in the region has induced the different ethnic groups of the region as well as the central governments to dominate the regional politics. Throughout the history, it has been a Tamil-speakers predominant province with 'Sri Lankan Tamils' as majority. Therefore, Tamils argue that the Eastern province is part of their traditional homeland with the Northern province. As a result, Tamil political leaders continued to claim that the Tamils should be given self-rule or autonomy to be politically independent in order to control their inhabited areas. On the other hand, the severe impact of ethnic conflict and civil war induced the Muslims, who form the second majority in the region to demand and advocate for a territorial autonomous unit covering their predominant areas in the region on a non-contiguous basis. However, these claims and arguments have received little support from the country's ethnic majority, the Sinhalese, who form about 75 percent of the country's population and predominantly living in the country other than the Northern and the Eastern regions. Therefore, when political power was transformed to Sinhalese from the British colonial, the immediate focus of Sinhalese was on the Eastern province. As to sabotage the minorities' claims for autonomy and power domination in the regional politics, Sinhalese-dominated successive governments made number of initiatives and implemented a number of policies and projects in the region, so as to ensure Sinhalese dominance in the administrative and political affairs. Irrigation-based land settlement projects were the major instruments to make affective change in the region's ethnic composition and to control lands in the province.

Similarly, although the constitutional and other legal provisions allowed the Eastern province to be conducted the daily administrative affairs in Tamil language, the province has been under the control of Sinhalese bureaucrats and the dominance of their language, Sinhala, up to now. This has imposed a number of challenges for Tamil-speakers, the predominant linguistic communities living in the region. Even at the political level, the region has continued to be under the control of Sinhalese Governors, appointed by the country's President, and the major portfolios of the provincial government have also been controlled by the Sinhalese provincial ministers in the postcivil war era. All these socio-development and political contexts urge an academic investigation into why Eastern province has been important for ethnic majority and Sinhalese rulers and how it has undermined the political autonomy of minorities in the region. The existing literatures show a clear gap in answering the above research problem; therefore, this study attempts to fill this gap. The major objective of this study is to examine the nature of and the driving forces for majoritarian dominance in politics, development, and administration in the Eastern province. The other objective is to examine the drive and challenges for political autonomy of minorities in the region and how their autonomy thirst and demands were viewed and accommodated by the ethnic majority and their politics.

\section{Methodology}

This study is qualitative in nature and has used mostly secondary data collected from different sources including literary books, book chapters, academic journals, newspaper articles, government reports, and websites. These sources have recorded and reviewed many discourses and changing dynamics of ethnic and power politics of ethnic groups for regional autonomy in the Eastern province and their recent developments. However, this study has taken a few thematic areas to test the ethnic and power politics for regional autonomy in the Eastern province. They are: (a) Politics of development and the question minorities' rights over land and territory, (b) Politics of language, linguistic dominance and the question of linguistic rights of minorities, and (c) Politics of provincial governance and the question of provincial autonomy rights of minorities. Also, this study has specially focused on the position of Muslims-who form a decisive majority in provincial population-in discourses on territoriality and regional autonomy in the Eastern province. The concerns and grievances of Muslims and their autonomy proposals have influenced in ethnic and power politics of Tamils and power dominance of Sinhalese in the region. This context induced us to place a special focus on the Muslims' part. 
This paper is divided into eight major sections. After a brief introduction and methodology parts, the next section reviews the historical background of the Eastern province, its demography and political-administrative profiles. The next part examines the impact of politics of development and land settlement projects on the land and territoriality concerns of minorities in the Eastern province, followed by the section examining the linguistic politics as a way to deny the linguistic rights of minorities in administration and as a means to dominate the provincial public administration. In the last part, before the discussion and conclusion sections, the representative politics and autonomy concerns in the provincial governance are extensively reviewed through examining the provincial council system as a mean to accommodate political autonomy rights of minorities in the region. The discussion part views the rationales behind the minorities' autonomy concerns and claims and the reactions of the ethnic majority to those claims. The conclusion section summarizes the major findings of the study and proposes alternative mechanisms to accommodate the territorial [land], linguistic and political autonomy concerns of ethnic minorities in regional governance.

\section{Eastern Province: Demographic, Administrative, and Political Profiles}

The Eastern province covers an area of about 10,000 sq. $\mathrm{km}$, which makes it the fourth biggest province in the country. According to the census of 2012, the Eastern province is a home for a population of $1,555,510$, which comprises the country's three major ethnic groups in a competing manner. Accordingly, the Tamils are the majority ethnic group in the region forming 39.5 percent in the provincial population. The Muslims (referred to as 'Moors') form the second majority with 37 percent while Sinhalese forms the second minority with 23 percent in provincial population (See: Table-1). The settlement pattern of ethnic groups is also important in the context of ethnic competition and power politics in the Eastern province. The province is divided into three administrative districts in which the Tamils form the first majority in Batticaloa, the second majority in Trincomalee, and the second minority in Amparai. The Muslims form the first majority in Amparai and Trincomalee districts and the second majority in Batticaloa district. The Sinhalese forms the second majority in Amparai district and the second minority in Batticaloa and Trincomalee districts. However, it is worth noting that this ethnic composition was artificially created through a number of development-cum-settlement projects as extensively viewed in Section-4 of this paper.

The Eastern province is one of the nine provinces, the first level administrative divisions in Sri Lanka. When the British gained control of the entire island of Ceylon in 1815, they divided the island into three ethnic-based administrative regions: one for law country Sinhalese, one for the Kandyan Sinhalese, and the next for the Tamils, where the eastern province was part of the Tamil unit since its population was predominantly Tamil-speakers (Tamils and Muslims). With the recommendation of Colebrooke-Cameron Commission in 1833, the ethnic-based administrative units were unified into a single central administration in which five provinces were created including the Eastern province in which Governors functioned as administrative heads. Later, these provinces were further divided into nine (Ranasinge, 2014; Yusoff et al., 2015a). Presently, for the administrative easiness, each province is now sub-divided into administrative districts and administered by the Government Agents (GA, also called as District Secretary). Both Governors and the Government Agent are directly appointed by the Head of the State, the President. The Eastern province is divided into three administrative districts, namely Amparai, Batticaloa, and Trincomalee which are sub-divided into 43 Divisional Secretariat (DS) divisions. The province is politically divided into 45 Local Government units (3 Municipal Councils, 5 Urban Councils, and 37 Pradesiya Sabhas), three Electoral Districts and 10 Constituencies, which elect 16 members to the central Parliament, and 37 members to the Provincial Council.

The provinces gained political importance when United National Party (UNP) government introduced Provincial Council system based on the Thirteenth Amendment to the constitution made in 1987, as a mechanism to accommodate minorities claims for self-rule or autonomy. However, in this system, the Eastern province was merged with the Northern province on a temporary basis as to fulfil the autonomy demands of Tamils without the concern from the people of Eastern province. This reduced the population strengthen of ethnic minorities in the region, particularly of Muslims 
who formed 33 percent earlier and became 17 percent later in the merged North-Eastern province. This also induced them to advocate for self-rule and a separate autonomous political unit for them in the region (See: Yusoff et al., 2014). The merger of these provinces continued till 2006 when the Supreme Court found the merger illegal and demerged the two provinces. The de-merger had a strategic importance for the Muslim community in the Eastern province, since they obtained the capability of living without the domination of any ethnic group and to ensure the attainment of their regional autonomy demand. However, the emerging ethnic context in the regional politics and the post-civil war political development little supported the Muslims [even the Tamils] to experience self-rule or autonomy in the region. As history recorded, the province continue to be controlled by the central government authorities, ethnic majorities-the Sinhalese, and their language-Sinhala in the entire post-independent era, as extensively discussed in the following sections.

\section{Politics of Development and the Question of Minorities' Rights over Land and Territory}

Land has been a contested subject in the affairs of competing ethnic and territorial politics in the Eastern Sri Lanka. The land settlement projects implemented by the successive central governments expecting to enhance regional development have also highly influenced in the demographic change and territorial demarcations in the Eastern province. Historically, the most territories of the Eastern province were under the control of Sinhalese kingdoms and the region was rarely under the control of the North nor was it part of the traditional home rule of Tamils. However, even before the independence, the Tamil politicians were claiming or advocating for a separate state or a federal unit covering the territories of the entire Northern and the Eastern provinces. This claim or advocacy is based on the argument that these regions are the traditional homeland of Tamils in which Tamils experienced a kind of self-rule. The formation of Federal Party (FP) under the leadership of SJV.Chelvenagayam was also partly based on the above argument and the party has continued to keep this as one of its major demands in its ethnic politics. This is a highly challenging concept and demand for the country's ethnic majority, the Sinhalese, as they have been advocating that Sri Lanka is a Sinhalese-Buddhist nation. Therefore, the Eastern province was the major target of Sinhalese rulers when they received power from the British colonists. At the time of independence, the Eastern province was entirely a predominant Tamil-speakers region, but most of their settlements were in the coastal areas or belt. Targeting the inland areas, the successive central governments initiated many irrigation-cum land settlement projects expecting to settle more Sinhalese, challenging the ethnic dominance of Tamil-speakers, and their autonomy demand in the region.

The successive governments policies with respect to population settlement and regional development in Eastern province have been characterized first by a regime of ethnic transmigration of Sinhalese populations, and second, by an effort to segregate all three ethnic groups into segregated zones of ethnic concentration (Routray \& Singh, 2007). In the immediate post-colonial period, the Sri Lankan governments engaged in a number of major irrigation and land settlement projects which provided preferential water access to upland Sinhalese populations and served as a platform for programs encouraging the systematic migration of Sinhalese populations into cleared jungle and populated Tamil-or Muslim-majority areas (Peebles, 1990). Thereafter, the upland areas of Eastern province have always had a Sinhalese majority population. These Sinhalese settlements induced a rapid decline of Tamil-speakers population in the region and also questioned the Tamil claim of continued or merged North-Eastern region as the autonomous or federal unit for them.

Starting from the Kantale irrigation-based settlement scheme in 1948 in the Trincomalee district, the land settlement project continued to other parts of the region; Gal Oya settlement project started in 1949 covering the Southern part of the Batticaloa district (presently the Amparai district) and Alle and Morawewa in the Trincomalee district and Mahaweli-E scheme in the border of Batticaloa district from 1950 up to 1980s (See: Hasbullah et al., 2005; Fonseka \& Raheem, 2010; Yusoff et al., 2015b). Under the auspices of the above-noted various irrigation-based land settlement and development schemes, Sinhalese peasants were encouraged from the 1950s through the 1980s to move into many parts of the Eastern province by providing them with irrigable agricultural lands and basic amenities. According to the ICG (2008), by the late 1960s, the 
government had alienated more than 300,000 acres of land to 67,000 allotters in these major colonization schemes. The settlement of so many Sinhalese in these districts which were, at independence, almost entirely Tamil-speaking, was politically explosive and emerged as one of the major grievances expressed by the Tamil and Muslim public, their political leaders, and the Tamil militant groups fought for the liberation of Tamils in North-Eastern region. This process of stateaided colonization was seen not only as a threat to the political and autonomy status of Tamils [and Muslims] but also a threat to the existence of Tamils community with its linguistic and cultural identity (Reddy, 2002).

These Sinhalese settlers were further empowered with the establishment of local government and administrative bodies, and electoral constituencies. Borders of these units were also redrawn, favoring these settlers. The ultimate result of these projects was the progressive increase of Sinhalese and the decline of Tamil-speakers in the regional population. The review of the census reports reveals that the Sinhalese population of 4.23 percent in the Eastern province in 1921 has increased to 24.99 percent in 1981 while the population strength of Tamils and Muslims has gone down progressively, as summarized in Table-1. Table- 2 and Table- 3 clearly summarizes the population changes in terms of ethnic groups in the districts of Amparai and Trincomalee, respectively.

Table 1: Population of Eastern Province by Ethnic Groups (1921-2012)

\begin{tabular}{|c|c|c|c|c|c|c|c|c|c|}
\hline \multirow{2}{*}{ Census Year } & \multicolumn{2}{|c|}{ Tamils (a) } & \multicolumn{2}{|c|}{ Muslims (b) } & \multicolumn{2}{c|}{ Sinhalese } & \multicolumn{2}{c|}{ Others } & \multirow{2}{*}{ Total } \\
\cline { 2 - 9 } & No & \% & No & \% & No & \% & No & \% & \\
\hline 1921 & 103,245 & 53.54 & 75,992 & 39.41 & 8,744 & 4.53 & 4,840 & 2.51 & 192,821 \\
\hline 1946 & 136,059 & 48.75 & 109,024 & 39.06 & 23,456 & 8.40 & 10,573 & 3.79 & 279,112 \\
\hline 1953 & 167,898 & 47.37 & 135,322 & 38.18 & 46,470 & 13.11 & 4,720 & 1.33 & 354,410 \\
\hline 1963 & 246,059 & 45.03 & 184,434 & 33.75 & 108,636 & 19.88 & 7,345 & 1.34 & 546,474 \\
\hline 1971 & 315,566 & 43.98 & 247,178 & 34.45 & 148,572 & 20.70 & 6,255 & 0.87 & 717,571 \\
\hline 1981 & 410,156 & 42.06 & 315,436 & 32.34 & 243,701 & 24.99 & 5,988 & 0.61 & 975,251 \\
\hline 2012 & 614,184 & 39.48 & 574,898 & 36.96 & 360,738 & 23.19 & 5,690 & 0.37 & $1,555,510$ \\
\hline
\end{tabular}

(a) Sri Lankan Tamils and Indian Tamils (b) Sri Lankan Moors and Malays

Source: DCS, 2007 \& 2014.

One of the districts that was seriously affected by land-cum-irrigation-based settlement schemes in the Eastern province is the Amparai district. Before the district was formed in 1961, Muslims and Tamils had been the predominant settlers in this area. Due to the implementation of the Gal Oya project, thousands of acres of lands owned by Muslims and by Tamils were seized by government authorities in order to settle more Sinhalese. As a result, the Sinhalese population progressively increased in the district, reducing the strength of Tamils and Muslims (See: Table-2). According to Hasbullah et al. (2005), under the colonization project, beneficiaries were selected overwhelmingly from the Sinhalese rather than the Muslims and the Tamils who formed a majority in the region at that time. Table-4 summarizes how the land was shared or allocated among the divisional administrative units predominated by ethnic groups in Amparai district.

Table 2: Changing Ethnic Balance in the District Population, Amparai (1963-2012)

\begin{tabular}{|c|c|c|c|c|c|c|c|c|c|}
\hline \multirow{2}{*}{ Census Year } & \multicolumn{2}{|c|}{ SL Muslims } & \multicolumn{2}{c|}{ Sinhalese } & \multicolumn{2}{c|}{ SL Tamils } & \multicolumn{2}{c|}{ Others } & \multirow{2}{*}{ Total } \\
\cline { 2 - 9 } & No & $\%$ & No & \% & No & $\%$ & No & $\%$ & \\
\hline 1963 & 97,621 & 46.11 & 61,996 & 29.28 & 49,185 & 23.23 & 2,930 & 1.38 & 211,732 \\
\hline 1971 & 126,365 & 46.35 & 82,280 & 30.18 & 60,519 & 22.20 & 3,441 & 1.26 & 272,605 \\
\hline 1981 & 161,568 & 41.45 & 146,943 & 37.78 & 77,826 & 20.01 & 2.633 & 0.67 & 388,970 \\
\hline 2007 & 268,630 & 43.99 & 228,938 & 37.49 & 111,948 & 18.33 & 1,203 & 0.20 & 610,719 \\
\hline 2012 & 281,702 & 43.40 & 252,458 & 38.90 & 112,457 & 17.30 & 2,785 & 0.40 & 649,402 \\
\hline
\end{tabular}

Source: DCS 2007 \& 2014. 
Table 3: Population of Trincomalee District by Ethnic Groups (1921-2012)

\begin{tabular}{|c|c|c|c|c|c|c|c|c|c|}
\hline \multirow{2}{*}{ Census Year } & \multicolumn{2}{|c|}{ Tamils (a) } & \multicolumn{2}{c|}{ Muslims (b) } & \multicolumn{2}{c|}{ Sinhalese } & \multicolumn{2}{c|}{ Others } & \multirow{2}{*}{ Total } \\
\cline { 2 - 8 } & No & \% & No & \% & No & \% & No & \% & \\
\hline 1921 & 18,580 & 54.47 & 12,846 & 37.66 & 1,501 & 4.40 & 1,185 & 3.47 & 34,112 \\
\hline 1946 & 33,795 & 44.51 & 23,219 & 30.58 & 11,606 & 15.29 & 7,306 & 9.62 & 75,926 \\
\hline 1953 & 37,517 & 44.71 & 28,616 & 34.10 & 15,296 & 18.28 & 2,488 & 2.96 & 83,917 \\
\hline 1963 & 54,452 & 39.30 & 40,775 & 29.43 & 39,925 & 28.82 & 3,401 & 2.45 & 138,553 \\
\hline 1971 & 71,749 & 38.11 & 59,924 & 31.83 & 54,744 & 29.08 & 1,828 & 0.97 & 188,245 \\
\hline 1981 & 93,132 & 36.39 & 75,039 & 29.32 & 85,503 & 33.41 & 2,274 & 0.89 & 255,948 \\
\hline 2012 & 117,873 & 32.01 & 159,127 & 41.92 & 101,483 & 26.74 & 1,058 & 0.28 & 379,541 \\
\hline
\end{tabular}

(a)Sri Lanka Tamils and Indian Tamils (b)Sri Lankan Moors and Malays

Source: DCS 2007 \& 2014

Table 4: Land Allocation Based on the DS Divisions Dominated by the Ethnic Group in Amparai District (2014)

\begin{tabular}{|l|c|c|c|c|}
\hline \multirow{2}{*}{$\begin{array}{l}\text { DS Divisions Dominated } \\
\text { by Ethnic Groups }\end{array}$} & \multicolumn{2}{|c|}{$\begin{array}{c}\text { Total Population } \\
(\mathbf{2 0 1 4})\end{array}$} & \multicolumn{2}{c|}{$\begin{array}{c}\text { Allocated Land for DS Divisions } \\
\text { Predominated by Ethnic Groups }\end{array}$} \\
\cline { 2 - 5 } & Amount & Percentage & Amount (KM $\left.{ }^{2}\right)$ & Percentage \\
\hline Muslims & 281,702 & 43.6 & 759.4 & 17.2 \\
\hline Sinhalese & 252,458 & 38.7 & 3248.5 & 73.6 \\
\hline Tamils & 112,457 & 17.4 & 407.1 & 9.2 \\
\hline Others & 2785 & 0.3 & - & - \\
\hline Total & 649,402 & 100 & 4415 & 100 \\
\hline
\end{tabular}

Source: Prepared by the researchers based on the data collected from District Secretariat, Amparai, 2013 \& DCS, 2014.

Even in the post-civil war context, issues over land remain in the Eastern province. According to the Provincial Council Act, land is listed as one of the subjects under the provincial council list, and is under the control of the provincial administration. However, in many instances, according to MRGI (2011), the then Chief Minister of the Eastern province tried to intervene on issues where provincial land has been claimed by the State and/or where complaints have been made to him of individual lands taken over by various authorities, where he had failed to have his views considered by the central government authorities. Specific ways in which the central government authorities appears to be involved in land issues in the Eastern province were: taking over land for security purposes or under various ministries; and supporting, assisting or sponsoring families from the Sinhalese community of the other districts or provinces to settle in the province.

In fact, as Yusoff et al. (2015b) argue, the land policies and land settlement projects have further induced the emergence of territorial-based political claims (territorial autonomy, self-rule and separate state) in Sri Lankan ethnic conflict. Every land settlement in the dry zone of the Eastern province has been a major source of grievances among Tamil-speaking minorities, contributing to the demands of territorial autonomy among the Muslims, and a separate state among the Tamils. A systemic review of the minority demands in the discourse of ethnic conflict reveals that stopping land seizures and land settlements in the Eastern region, and granting more autonomy in terms of land affairs to the Northern and the Eastern provincial councils were the two major claims of ethnic minorities (See: Hasbullah et al., 2005; Uyangoda, 2009; Fonseka \& Raheem, 2010; Sarjoon, 2011; Fonseka \& Jegatheeswaran, 2013). On the other hand, state-owned and state-sponsored colonization programs, in particular, have been heavily criticized and often targeted by the Tamil fighters, accusing these programs as an effort to expand the Sinhala frontier into the so-called 'Tamil homeland.' We discuss this matter extensively in the discussion section. 


\section{Politics of Language, Linguistic Dominance and the Question of Linguistic Rights of Minorities}

Language is one of the leading causes of ethnic conflict in Sri Lanka. The language problem has its roots in the 1956 Official Language Act, which substituted Sinhala alone for English as the official language. Although the 1957 Official Language Special Provision Act allowed public administration to be conducted in Tamil in the Northern and the Eastern provinces, Tamil legally became an official language with the adaptation of $13^{\text {th }}$ and $16^{\text {th }}$ amendments to the present (1978) constitution, in 1987 and 1988, respectively (See: Parliament Secretariat, 2015). This status for Tamil is further ensured with the enactment of the Official Languages Commission Act (No.18) of 1991, as well as government directives through the number of gazette notifications and public administration circulars (See: FCE, 2006; Yusoff et al., 2015a). However, the functioning of the public administration in Tamil in the Eastern province has always been a contested matter with regard to ethnic politics and provincial autonomy.

It is worth noting that about four-fifths of the regional population in the Eastern province are Tamil-speakers. However, Tamil-speaking public and public officers continue to receive letters, circulars or any kind of communication from the ministries and the departments in Colombo in Sinhala language. In some districts, particularly both in Amparai and Trincomalee in the Eastern province, the District Secretaries (or Government Agents), who represent the central government in the administrative system and wield considerable authority, are always of Sinhalese with no or poor knowledge of Tamil language. The gradual increase of Sinhalese population in the region has led to increase their domination over the local administration in the region. The above-noted two Tamilspeakers' predominant districts, have continued to be administered by the Sinhalese District Secretary and bureaucrats.

Similarly, the head of the provincial administration, the Governor, was also appointed from the Sinhalese. It is found that six Governors were appointed for the merged North-Eastern province from 1988 to the end of 2006, and two Governors were appointed for the Eastern provincial council from 2007 to up to the end of 2018, but none of them were appointed from Tamil-speaking communities while there were constant demands and expectations among them. The appointment of District Secretary and other administrative officers from the same ethnic groups (Sinhalese) over representing their ethnic ratio in district population easily allowed them to control administration and to violate the linguistic rights of Tamil-speakers living in the region. Tamil-speaking minorities find it not only the violation of constitutionally guaranteed linguistic rights but also the rights to administer their affairs in their own or familiar language. This clearly shows the violation of constitutional provisions in terms of minority rights accommodation-another means to undermine the linguistic identity and rights of minorities as part of undermining their self-rule or autonomy claims.

\section{Politics of Provincial Governance and the Question of Provincial Autonomy Rights of Minorities}

The idea of granting autonomy or establishing autonomous political entity to regionally concentrated ethnic groups has evolved in Sri Lanka even before independence. In 1926, SWRD. Bandaranaike, who returned from British education proposed federalism as the best model to accommodate the autonomy claims of ethnic groups in Sri Lanka. After he became the country's Prime Minister in 1956, Bandaranaike offered the Tamil leaders the important concession of setting up regional authorities called 'regional councils' with powers on regional development, education, land, healthcare, water schemes, roads and colonization, through the popularly known Banda-Chelva Agreement. This agreement also agreed to adopt provision for establishing one 'Regional Council' for the Northern province, and two or more Councils for the Eastern province. The FP, while repeating its demands for federal state accepted this agreement as 'an interim adjustment' (Nawarathna-Bandara, 2000). However, this first initiative for granting regional autonomy for ethnic communities particularly in the Eastern province became unsuccessful due to the vehement opposition emanating from the imperative Sinhalese-Buddhist ethno-nationalism, which had dominated the Sri Lankan politics in 1950s. Although there were some initiatives on establishing 
territorial-based autonomous councils as a political mechanism to resolve ethnic grievances of minorities, most of them have failed due to the oppositions emanated from the negative understanding of the concept of regional autonomy and because of the domination of majoritarian ethno-nationalism in national politics.

From the 1970s, the democratic political system and territorial integrity of the country came under threat. An insurrection in the Southern part of the country by the Sinhalese youth, known as Jantha Vimukthi Peramuna (JVP) and the youth movements in the North-Eastern regions manly led by the Liberation Tigers of Tamil Eelam (LTTE) and others, influenced the state reform process significantly. During this period, there were some proposals for accommodating self-determination claims of Tamil-speaking people based on federal structure within the united Sri Lanka. However, they did not receive the focus of rulers. Therefore, from the early part of the 1980s, Sri Lanka experienced a gradual intensifying of civil war, and Tamil-speakers were demanding more autonomy and self-rule, even separation in their traditional homeland. The LTTE and the other movements became increasingly violent due to lack of state mechanism to accommodate their autonomy claims and interest in regional governance structure.

From 1985 onward, the government of Sri Lanka was seen toward a military solution to separatist and terrorist claims and campaigns of the LTTE and other Tamil militant groups. This induced the Indian intervention in Sri Lankan ethnic conflict. Faced with the possibility of an active Indian intervention, Sri Lanka government commenced negotiation with the Indian counterpart. This led eventually to the signing of Indo-Sri Lanka Accord on $29^{\text {th }}$ July 1987 (Lakshman, 2017). Accordingly, Thirteenth Amendment to the constitution was adopted on $14^{\text {th }}$ November 1987 and provincial councils were established for every province, as specified in the $8^{\text {th }}$ schedule of the constitution. The provincial council was expected to function as a politically decentralized institution.

The Indo-Sri Lanka Accord insisted the merging of the Eastern province with the Northern province to make it into one provincial council as an interim arrangement to accommodate the political autonomy claims of Tamils. The accord included a provision for a referendum to be conducted within the Eastern province by the end of 1989 in order to decide whether or not the Eastern province should continue to remain merged with the North. The merged North-Eastern province was declared by the President in 1988. Like other provincial councils, election to the newly formed North-Eastern provincial council was held on $19^{\text {th }}$ November 1988 . The referendum in the Eastern province, however, was never conducted and the successive Sri Lankan Presidents issued proclamations annually, extending the life of the temperately merged entity till 2006 (Lackshman, 2017).

The introduction of provincial councils was meant to ameliorate the demands particularly of the Tamil community, who sought a separate state or tangible autonomy for the Northern and Eastern provinces in Sri Lanka. However, the provincial councils, which fell far short of federalism, nevertheless, introduced the meaningful devolution of power. When it comes to practice, particularly in the Northern and the Eastern regions, the central government authorities strategically put mechanisms to control or undermine the exercise of the 'so-called devolved powers' by the provincial council or the council of ministers. It is worth noting that the Provincial Council Act devolved land and police powers to the provincial councils, but the central government authorities denied those powers to exercise by the North-Eastern provincial council, and council of ministers. This was the major reason for the Chief Minister of the merged North-Eastern province and the leaders of Eelam People Revolutionary Liberation Front (EPRLF), A.Waradaraja Perumal to oppose the provincial council system and to pass a resolution in the provincial council in favour of a separate state for Tamils. This was ultimately led to the dissolution of the North-Eastern provincial council in one year survival.

The merger of Northern and the Eastern provinces together was bitterly opposed and campaigned negatively by the Sinhalese-Buddhist nationalist forces and parties. Ultimately, a Supreme Court ruling in October 2006, made a response to a case filed by the JVP, which eventually produced the de-merger of the two provinces permanently founding it unconstitutional, illegal, and invalid (Asian Tribune, 2006). The de-merger came eventually in January 2007 and provision was made to set up the Provincial Council each in the Northern and the Eastern provinces. The Tamils view this as a major challenge to achieve their self-rule or autonomy claims 
in the traditional homeland of the merged North-Eastern region.

After the de-merger, the people of Eastern province were able to choose their elected representatives. However, ethnic minorities continued to expressed their worries about the dominance and rigid control of central government authorities, Sinhala language, and administrative elites mostly Sinhalese in the affairs of administration, development, and politics of the province. This, in turn, in many ways helped undermine their expectations for exercising self-rule and autonomy in the region.

\subsection{Politics of Representation and Regional Autonomy of Tamils and Muslims in the East}

Self-determination and self-government have been the critical demand of minority ethnic groups for over half a century in Sri Lanka. During the ethnic conflict and civil war, there have been attempts by successive Sri Lankan governments to discuss some form of political autonomy for minorities, mainly for the Tamils. However, the status of the Eastern province, and locating it within the powersharing mechanism have continued to be a contested matter in the process of state-building and territorial autonomy discourse in Sri Lanka. This issue has continued even after the de-merger of the North-Eastern provinces and its influence in its electoral politics. The electoral politics has made the Eastern province the stage for power competition between the major ethnic groups. The Muslim community has become the special target of two ethnic majorities, the Sinhalese and the Tamils, as the major supporters to gain control of the Eastern provincial council as to exercise a kind of selfrule and autonomy in the region.

In the last two decades, following a change in the electoral system to a proportional representation system, the minority political parties have played an influential role in Sri Lankan politics. Sri Lanka Muslim Congress (SLMC), which is the largest Muslim political party, has been in the position to make and break governments. The SLMC has emerged out of the political marginalization and grievances of Muslims of the Eastern [and the Northern] provinces in the early 1980s. The ethnic politics and the vulnerable position of the Muslim community due to violent civil war made the SLMC the major political voice and a representative body for Muslims in the national parliament and provincial councils (Yusoff et al., 2017). Therefore, though the SLMC opposed the merging of the Eastern province with the North, it contested the first election for the merged NorthEastern provincial council held in 1988 and became the main opposition party in the council. During this election, ethnic sentiments were highly motivated. There have only been ethnic competition among three major ethnic groups. This led the SLMC to secure the highest Muslims votes and representations in the election although the Muslims in the region had a habit of supporting and voting the two major pro-Sinhalese parties, the UNP and the SLFP.

With the opposition leadership, the SLMC voiced the grievances of the Muslim community and advocated for their rights and privileges in the North-Eastern provincial council. Although this council was dissolved in one year period by the President, this electoral victory driven the SLMC became influenced in national politics. In the successive elections, with the increase in public support and representations, the SLMC became the major political force that could influence to determine the destiny of national politics. This ultimately made the SLMC as the 'Queen-maker' in 1994 and the successive general elections in the new millennium (Yusoff et al., 2017).

The more ethnic-based demands and their advocacy by the SLMC brought more criticisms and oppositions to the SLMC in national politics. With the sudden demise of its founder, MHM.Ashraff, in September 2000, however, the SLMC became fragmented and more Muslims political parties mushroomed. When election was declared to the newly formed Eastern provincial council in 2008, the winning the majority Muslim representations in the council became the major target of the SLMC. At that time, a tri-polar competition among Muslim political parties was existing. This has helped the-then President Rajapaksa and the UPFA leaders to convince the two major Muslim parties to their alliance while promising the Chief Minister (CM) post for Muslim winning candidate. There were huge demands among the Muslim civil society urging all Muslim parties to unite and contest the election under a common symbol. The SLMC, however, was not ready to conceal its tree symbol; therefore, unification failed and as usual it contested with the UNP, the main opposition party at that time. The SLMC leader, Rauff Hakeem, its chairman, Basheer Segu 
Davood, and its secretary general, Hasan Ali, resigned from their seats in the central parliament and contested the provincial council election as leading candidates under the UNP ticket in three districts of the Eastern province (Yusoff et al., 2014). Although the elections produced results favouring Muslims, due to disagreement and fragmentations within the Muslim parties, they could not achieve the CM post nor receive any influential provincial ministries.

On the other hand, the major Tamil political party, the Tamil National Alliance (TNA), had boycotted the 2008 provincial council election arguing that the de-merger of the North-Eastern provinces had undermined the self-determination rights of the Tamil people. This decision helped the newly-formed Tamil Makkal Vidutalaip Puligal (TMVP) headed by Pillaiyan, alias Sivanesathurai Chandrakanthan to make an alliance with the ruling UPFA government. The UPFA had agreement with the TMVP to offer the CM post if they could receive more representatives in the council. Even though eight Muslims and six Tamils were elected from the UPFA list in the election indicating that the Muslims were the majority elected under the UPFA list, the UPFA leader, President Rajapaksa, after a long political turmoil, appointed Pillaiyan as the CM of the Eastern province (See: Yusoff et al., 2014). However, UPFA leaders strategically controlled the Eastern provincial council by appointing Sinhalese to the most important ministries such as land and education, expecting to expand their dominance over the province. This has helped them implement a number of policies and projects in the province favouring Sinhalese and to extend their dominance in the post-war development and governance process. During this period of provincial council, both the Muslim and Tamil councillors expressed their disappointment in regard to their ministerial positions and expectations in provincial governance. Hisbullah, the then provincial minister of health, openly revealed the inefficiency of his ministerial position at one point. Although the UPFA-led government made number of initiatives for post-civil war development in the region, the control of the entire development and provincial administration was at the hand of central government ministers and the provincial Governor, who was appointed by the President.

With the failure to control provincial administration in 2008, there have been continuous discourses among the Eastern Muslims on controlling the provincial council in the forthcoming election. Although election to the Eastern provincial council was due in 2013 only, President Rajapaksa dissolved it early and fixed the election on $8^{\text {th }}$ September 2012. Both major political parties started to make an alliance with the influential parties in the East. This time, an important change of the political context in the electoral politics of province was the TNA's announcement to contest the provincial council election. The TNA contested the election under The Ilankai Tamil Arasu Kadchi (ITAK).

Since Muslims formed a decisive majority in the provincial population (it was projected as 40 percent in 2007, but actually was 37 percent, according to the 2012 census (DCS, 2014)), both the UPFA and the TNA invited the SLMC for electoral coalition, while there were more demands for the SLMC from the Muslim community to contest the election alone or with other Muslim parties. However, the SLMC was not in favour of conducting the election under a common symbol for the sake of Muslims but only favoured being with the UPFA alliance. When the coalition negotiation with the UPFA failed; mainly due disagreement on the matter of establishing a Muslim predominant administrative district in the coastal belt of Amparai district before the election, the SLMC decided to contest the election alone under its own symbol believing only in its traditional Muslim loyalties, while there were demands for Muslim coalition (Yusoff et al., 2014).

The 2012 provincial council election produced the SLMC again the 'King-maker' in forming the provincial government. While no party received majority to form the government, the seven seats gained by the SLMC became a decisive number to form the government. The TNA openly announced that they are willing to concede the CM post to the Muslims if the SLMC agreed to form a provincial government with TNA (Colombo Telegraph, 2012). However, believing that the consensus reached with the UPFA, so as to fulfil the rightful rights of Muslims in the provincial administration, which would enable them to gain autonomy to some extent, the SLMC leaders supported the UPFA to form provincial government. In fact, the UPFA leaders convinced the SLMC in this regard. However, not the SLMC nor any Muslim political party were able to gain any important ministry in the provincial government, although two councillors were appointed as Chief Minister from Muslim members during the period of this council, they acted as rapports, for which 
the central government authorities had major control over. The Sinhalese ministers with the provincial Governor extended their ultimate dominance in the affairs of the provincial administration, governance and development.

The defeat of Rajapaksa regime in early 2015 tremendously influenced Sri Lanka's national politics. Ethnic minorities played vital roles in defeating President Rajapaksa and his government in the elections held in 2015. This increased the importance of the minority political parties in Sri Lanka's national and regional politics as well. The TNA became the major opposition party in parliament after the 2015 general election. This regime change has also influenced the provincial politics in the East and induced the new rulers to initiate a coalition with the minorities, particularly with the Tamils, to survive and control the Eastern provincial council and governance. This time, the UPFA formed a coalition government with the TNA while merely accommodating the Muslims' interests to the so-called 'political positions.'

While keeping the SLMC and other Muslim parties as coalition partners in the Eastern provincial council, the UPFA-led government was able to convince these parties to act in favour of their decisions or to endorse the provincial approval for many legal, political, and policy decisions taken to favouring the regime. Whenever the support of these parties were expected, and decisions were endorsed, these minority parties extended their supports believing on the promise that they could enjoy a greater level of autonomy and control over the provincial governance and administration. However, throughout the period of the council, the ethnic minorities' expectations in many matters related to ensuring their interests for autonomy has continued to be side-tracked or unsuccessful. The appointment of the provincial Governor from the Tamil-speaking communities, proper implementation of Tamil as official language, appointment of Tamil-speaking officers as District Secretaries in Amparai and Trincomalee districts, granting police and land power to the provincial council, establishing a Tamil-speakers' predominate administrative district in the coastal belt of the Amparai district for the administrative easiness of Tamil-speakers were some the continuous demands put forward by the Tamils and Muslims in the province, so as to ensure a kind of administrative and political autonomy in their part in the province. However, none of these demands were positively viewed and accommodated by the central government authorities except the appointment of provincial Governor from Muslim politicians in the early 2019 (He too was forced to resign from his post due to the pressure of Buddhist nationalist forces in early June 2019).

However, in terms of electoral politics in the Eastern province, with the results of the two elections not producing any single party a clear majority to form the provincial government, the Eastern provincial council has become a testing ground for political competency and maturity of any national and minority political party in their effort to establish a provincial government and administration with an absolute majority and to run the council without any disruption. The election scenarios have also emphasized the importance of ethnic cohesive politics in the region rather than advocating ethnic group dominance or autonomy in the future.

\section{Discussion}

The regional politics and governance in Eastern Sri Lanka has continued to be a contested matter due to the competing ethnic composition in the region and the power dominance of the ethnic majority over regional development, administration, and governance. Although the Tamil-speaking minorities, the Tamil and the Muslims, form the majority in the province, the provincial administration and governance continue to be controlled by the Sinhalese and their interests. The continuous claims of ethnic minorities for political autonomy and self-rule in the regional governance and administration were mostly responded negatively. There are fears among the majority Sinhalese and their leaders that granting more autonomy to this regional council will be merely a springboard to secession. However, autonomy and decentralization are seen by experts and governments as favourable tools in accommodating minority concerns and grievances in regional governance.

Therefore, there is a need for constitutional reform to provide more political and administrative autonomy for minorities in the Eastern province by examining the limitations of the existing legislative framework and analysing the most recent proposals. Although the existing devolution 
arrangement under the Thirteenth Amendment of the present constitution provides some level of devolved powers to the provinces [regions], this amendment is limited both on paper and in practice. Therefore, the Thirteenth Amendment is far from sufficient in fulfilling the minorities' aspirations to self-rule in the North and the East and there is a need to think and work beyond this limit so as to share more powers to the regions and to grant more autonomy to the regionallyconcentrated ethnic groups in deciding their own regional affairs.

\subsection{Tamil vs Muslim interests for regional autonomy in the East}

It is found that there are different motives and aspirations among different ethnic groups in terms of claims for regional autonomy and self-rule in the Eastern province. Although the Tamils and Muslims are living together, sharing a number of commonalities in the region, and having been collectively advocating for their rights and privileges from independence, including the equal status to Tamil language and for greater regional autonomy, where the two communities have a different perspective of autonomy for any minority in the region. Even before the independence, Tamils have been arguing that the Eastern province is part of their traditional homeland of merged North-East. In the 1977 election manifesto, the Tamil United Liberation Front declared an area slightly beyond the present borders of the combined Northern and Eastern provinces to be 'the exclusive homeland of the Tamils.' By the 1980s, the East was at the heart of the militant Tamil nationalist struggle to create a separate state of Tamil Eelam.

On the other hand, when the civil war became severe from 1980s onward, it negatively impacted the Muslim community and further increased their grievances as a result of the negligence of Tamil leaders. The government proposal to merge the Eastern province with the North also contributed to increase a sense of marginalization in the political settlement process among the Muslims in the East. These factors induced them to conceptualize and call for a Muslim predominant political autonomous unit for their security and ethnic identity based on the Muslimpredominant territories in the East. From 1980s onward, Muslim political forces, particularly the SLMC, have been proposing a Muslim majority political autonomous unit and articulating it as a political mechanism on the Muslim part in the ethnic conflict resolution process (Yusoff et al. 2014; Sarjoon 2011; McGilvray \& Raheem 2007). However, this was viewed by the Tamil nationalists and militant groups as opposed to their long-term demand of self-rule in their traditional homeland covering the entire and contiguous North-Eastern region. Therefore, Muslim autonomy demand was always criticized and challenged by the Tamil nationalists. However, both ethnic groups and their leaders continued to advocate their autonomy claims in the North-Eastern region in which the status of the Eastern region has always been a hot topic of debate during their advocacy.

As noted earlier, it is worth noting that the popular Sinhala and Tamil leaders, Bandaranaike and Chelvenayagam, in their agreement in 1957, made a provision to form two or more autonomous units in the Eastern province to ensure the autonomy and self-rule of major ethnic groups living in the region (See: Ghosh, 2003). As Jeyaraj (2016) argues, Chelvanayagam's approach is a recognition of regional and sub-national differences within the North-Eastern region. This further indicates the importance of ensuring shared rule or self-rule for ethnic groups in the region.

When the demerger of the two provinces became successful in 2006, both Tamils and Muslims eagerly engaged in regional politics, expecting to form a provincial government that would ensure them autonomy in due time. Therefore, when the election was called for the Eastern provincial council, the SLMC, since it has been advocating for Muslim autonomous unit in the region, actively participated in the election. However, the more fragmentations and opportunisms in Muslim politics undermined the ability of Muslim political forces to gain influence in elections and control the provincial governance, as viewed earlier in this paper. On the other hand, a noteworthy fact is that although the Tamil nationalist forces and liberal groups undermined the Muslim autonomy in the East, the Muslims leaders have been thorough in not opposing the demands and aspirations of Tamils on the matter of political autonomy. Only in the recent year, the political leaderships of the Tamil community have accepted the self-rule concept of Muslims in the East and expressed their willingness to establish an autonomous unit for Muslims when it comes to resolving 
the ethnic conflict by merging the Eastern province with the North. Similarly, many Muslims seem to have a realistic perspective that establishing an autonomous unit for Muslims by territorial merging of Muslim pockets in some kinds in the North-Eastern region must be an inevitable part of a political settlement to address Tamil grievances (McGilvray \& Raheem, 2007). However, there is a need for more mutual dialogs in this regard between the political and civic leaders of both ethnic groups.

The Sinhalese criticisms and opposition to merge the Eastern region with the North, or to grant more autonomy to the Eastern provincial council has also arisen based on the arguments that the East was not always been part of, or under the control of the North. Accordingly, the major territories of the Eastern province were under the control of Sinhalese kingdoms of the so-called dry zones centred in Anuradhapura and later in Polonnaruwa. Today's Batticaloa and Amparai districts were under the control of the South-Eastern Sinhalese Ruhuna kingdom of 300-200 BCE. However, the Sinhalese and Buddhist presence in the East had all but disappeared by the thirteenth century, except for a small number of widely scattered Sinhalese settlements in the forested areas at the foothills of central hill country due to South Indian invasion and the expansion or influence of Jaffna kingdom in the region. As McGilvray (2008) argues, the collapse of the Sinhala dry zone kingdoms in the thirteenth century opened the way for the slow 'Tamilisation' of the Eastern province.

Based on the above argument, in the post-independence era, the successive central governments attempted to equate the ethnic compositions in the districts of the Eastern province by implementing number of state-aided development-cum-land settlement projects as viewed earlier. Sinhalese found that granting land to the Sinhalese in the province is a positive process aimed at distributing land to the landless. There is also a perception among the Sinhalese that they are not stealing land from minorities but are merely re-claiming land that they abandoned centuries ago. They further claim that the process of land settlements in the North-Eastern region is to establish inter-racial equity (Marga, 1985). Therefore, the settlement of more Sinhalese through statesponsored land settlement programs, and the control of central government authorities in opposition to autonomy interests of Tamils and Muslims in the region were justified in this line. Yusoff et.al. (2015b) argue that the Tamil separate state (homeland) demand and the Muslim demand for an autonomous political unit, to a considerable extent, have challenged the ability of the central government authorities to control land in the Eastern province.

Similarly, the successive central governments have also used land settlement schemes to undermine the Tamils' claims of merged North-East as their traditional homeland. The settlements of more Sinhalese on the borders of districts in the Eastern provinces were motivated towards this line. There was no initial plan to turn the Mahaveli river to the North-Eastern region, but later, the UNP government purposively turned it in two areas to settle more Sinhalese as buffer zones in challenging the concept of traditional homelands for Tamils. Settling the Sinhalese at the border of the Eastern province with the North (at Weli Oya), and between the Trincomalee and Batticaloa boarder (at Weliganda area) was designed in this regard. The Tamil nationalists find this process as an attempt at bifurcating the North from the East with a string of Sinhalese settlements and to undermine their autonomy demands in the East (Yusoff et.al., 2015b).

On the other hand, the other factors also may have motivated government authorities to keep the control of the Eastern province in their hand. Eastern province is enriched with natural resources valuable to the country's national economic benefits. Forests, agricultural lands, wetlands, lagoons, sea ports, and attractive beaches are prominent among these resources. Above all, there has been a well-established ancient irrigation system in the province, which supports the full potential of agricultural production. The Trincomalee district has a natural harbour, which played a strategic role during the world wars and the civil war period in Sri Lanka. The state-aided settlements of the Sinhalese are mainly located in these resource basins and other strategic locations in the province. These settlers have been controlling the economic and administrative affairs of districts as well as in the province to a considerable extent. There is a fear among Sinhalese and rulers that granting more autonomy in the hand of ethnic minorities, the Tamils and the Muslims, may directly and indirectly challenge the interests and dominance of Sinhalese. There is no assurance that the regional autonomy to the Tamils and Muslims will ensure the rights and interests of Sinhalese living as pockets in the regions. This can be one of the major reasons for Sinhalese and their political leaders in opposing or unfulfilling the Tamil-speakers' demands with 
regard to the provincial governance and administration.

Similarly, Sinhalese leaders feel that granting autonomy for minorities in the North-East region would easily promote regionalism and secession that will ultimately challenge the territorial integrity of the country. This feeling ultimately helps mobilise the Sinhalese masses to challenge any minority demand for autonomy or self-rule as a threat to national and territorial integrity of the country, through which minorities will attempt to establish new states easily. These feelings and fears progressively motivated the central government authorities and the ethnic majority easily undermine any claim coming from ethnic minorities in the region for regional or territorial autonomy and self-rule.

\section{Conclusions}

Self-determination and self-government have been the critical demands of minority groups expecting to exercise more autonomy in political and administrative affairs in their predominant regions for over half a century in Sri Lanka. The Eastern province has been a contested region in terms of ethnic and minority politics and politics for autonomy compared to other regions in Sri Lanka. The ethnic composition in the region has been highly influential in ethnic relations, ethnic conflict, ethnic politics, development and governance in the region. Ethnic minorities, the Tamils and the Muslims, though they possess the majority in the provincial population, could not enjoy autonomy and devolved power in the affairs of regional governance and administration. They have always been controlled by the central government authorities or regimes, which have used them as tools for fulfilling their political interests and agendas in the province. Therefore, from the beginning of independence, the pro-Sinhalese political parties and regimes were able to easily implement a number of policies and projects to settle more Sinhalese in the region, targeting to undermine ethnic composition of minorities in the region, while failing to implement the policies and laws recognizing Tamil as the official language equal to Sinhala in public administration, but allowing the domination of Sinhala language at an extreme level, refusing to grant constitutionally-guaranteed devolved power in the affairs of provincial police and land, and expanding the dominance of the central regime in the political and administrative apparatuses of the provincial government.

In fact, all of the above identified factors have motivated the intensified ethnic conflict and civil war in the region that has further challenged the exercising of powers and autonomy of minorities in the region in one hand, and induced the over claims for autonomy, self-rule, and separation on the other hand. Since the protected civil war has ended, and all the minority political parties and civil forces have abandoned the separatist claims, ensuring regional autonomy for minorities has become important in the process of post-civil war transition and political settlement in Sri Lanka. Territorial or regional autonomy and decentralization are considered as best tools to accommodate minority concerns and claims for self-and shared-rule within the unitary system of government. There are a number of successful cases around the world in which territorially concentrated minorities are granted more autonomy to decide their own political and administrative affairs while maintaining their ethnic and regional identities, and preserving national and territorial integrity of the country.

When the state faces territorial autonomy demands from competing ethnic groups in a multiethnic region, granting more autonomy to the regional-based political council can accommodate the groups' concerns within the united country, to a considerable extent. Therefore, in the post-civil war context, implementation of the territorial or regional autonomy policy is critically important to enhance the relationship of equality, unity, and mutual co-existence among different ethnic groups, to uphold national integration, and to accelerate the development of places within the region and prosperity for all ethnic groups. However, in Sri Lanka, political autonomy, power-sharing, and decentralization still remain largely debated subjects. Initiatives for conceptual clarification and understandings among ethnic majority, national political leaders, and regional minorities together with mass education are highly needed in this regard. 


\section{References}

Asian Tribune, (2006), Judgment on North East demerger. 17 October. [Online]. Available: http://www.asiantribune.com/index.php?q=node/2578 (June 30, 2016).

Colombo Telegraph, (2012), TNA stake the claim to form the eastern provincial administration together with the SLMC and UNP. [Online]. Available: https://www.colombotelegraph.com/index.php/tna-stake-the-claim-toform-the-eastern-provincial-administration-together-with-the-slmc-and-unp/ (March 10, 2016)

DCS [Department of Census and Statistics]. (2007). Special enumeration - Eastern province 2007. Colombo: DCS.

DCS [Department of Census and Statistics]. (2014). Census of population and housing-2012 (New) - Final report. Colombo: DCS.

District Secretariat, Amparai. (2013). Annual performance report and budget 2012. Amparai: District Secretariat.

FCE [Foundation for Co-Existence]. (2006). Language discrimination to language equality: report of an audit on the status of the implementation of the official language policy in Sri Lanka. Colombo: FCE.

Fonseka, B., \& Jegatheeswara, D. (2013). Politics, policies and land acquisition and related issues in the north and the east of Sri Lanka. Colombo: Center for Policy Alternative.

Fonseka, B., \& Raheem, M. (2010). Land in the eastern province: politics policy and the conflict. Colombo: Center for Policy Alternative.

Ghosh, P.S. (2003). Ethnicity versus nationalism. Colombo: Vijitha Publications.

Hasbullah, S.H., Balasundarampillai, P., \& Tudor Silva, K. (2005). Addressing root causes of the conflict: land problems in the north-east Sri Lanka. Colombo: Foundation for Co-Existence.

ICG [International Crisis Group]. 2008. Sri Lanka's eastern province: land, development, conflict. Brussels: ICG. Jeyaraj, D.B.S, (2016), Tamil leaders opposed when Sinhalese leaders proposed federalism. Daily Mirror. 0801-2016. [Online]. Available:: http://www.dailymirror.lk/article/tamil-leaders-opposed-when-sinhaleseleaders-proposed-federalism-102393.html (February 25, 2018).

Lakshman, W.D. (2017). Developmental role and financing of sub-national units of government: the case of provincial councils in Sri Lanka. In N.S.Cooray \& S.Abeyratne (Eds.), Decentralization and Development of Sri Lanka within unitary state (pp.33-60). Singapore: Springer.

Marga Institute, (1985). Inter-racial equity and national unity in Sri Lanka. Colombo: Marga Institute.

McGilvray, D.B. (2008). Crucible of conflict: Tamil and Muslim society on the east coast of Sri Lanka. Durham: Duke University Press.

McGilvray, D.B \& Raheem, M. (2007). Muslim perspectives on the Sri Lankan conflict. Washington: East-West Center.

MRGI [Minority Rights Group International]. 2011. No war, no peace: the denial of minority rights and justice in Sri Lanka. London: MRGI.

Nawarathne-Bandara, A.M. (2000). Ethnic relations and state crafting in post-independence Sri Lanka. In W.D. Lakshman \& C.A. Tisdell (Eds.), Sri Lanka's development since independence: socio-economic perspectives and analysis (pp.113-126). New York: Nova Science Publishers, Inc.

Parliament Secretariat. (2015). The constitution of the democratic socialistic republic of Sri Lanka (As amended up to $15^{\text {th }}$ May 2015). Colombo: Parliament Secretariat, Parliament of Sri Lanka.

Peebles, P. (1990). Colonization and ethnic conflict in the dry zone of Sri Lanka. The Journal of Asian Studies, 49(1),30-55.

Ranasinge, R.A.W. (2014). The role of government agent in local administration in Sri Lanka. International Journal of Education and Research, 2(2), 1-14.

Reddy, L.R. (2002). Sri Lanka past and present. New Delhi: APH Publishing Corporation.

Routray, B.P \& Singh, A. K. (2006). The pawns of war. South Asia Intelligence Review 5(12). [Online] Available: http://www.satp.org/satporgtp/sair/Archives/5 12.htm\#assessment2 (May 20, 2017).

Sarjoon, A. (2011). Changing dynamics of minority rights discourse in Sri Lanka's eastern province: a study of the Muslim demand for autonomy. M.Phil Thesis, Colombo: University of Colombo.

Uyangoda, J. (2009). Sri Lanka: recent shift in the minority rights debate. In R. Manchanda (Ed.). Living on the margins: minorities in South Asia, pp.99-120. Katmandu: EUROASIA-NET Partners.

Yusoff, M. A., Sarjoon, A., Asrinaldi \& Mohd Zain, Z. (2015a). Decentralized administration and minority accommodation in Sri Lanka: analyzing status, issues, challenges and prospects. Mediterranean Journal of Social Sciences, 6(4S1), 533-542.

Yusoff, M.A., Hussin, N., \& Sarjoon, A. (2014). Muslim demand for territorial autonomy in the Eastern Sri Lanka: an analysis of its origin, accommodation and the present stance. Asian Social Science, 10(15), 76-88.

Yusoff, M.A., Sarjoon, A., Awang, A \& Hamdi, I.H. (2015b). Land policies, land-based development programs and the question of minority rights in eastern Sri Lanka. Journal of Sustainable Development, 8(8), $223-233$.

Yusoff, M.A., Sarjoon, A., Hussin, N., \& Ahmed, A. (2017). Analyzing the contributions of the Sri Lanka Muslim Congress and its founder-leader to Muslim politics and community in Sri Lanka. Social Sciences, 6, 120. 